DOI https://doi.org/10.30525/978-9934-26-039-1-45

\title{
ДИХОТОМІЯ ДОБРО-ЗЛО В ДАВНЬОІРАНСЬКОМУ МОВНО-КУЛЬТУРНОМУ ПРОСТОРІ
}

\author{
Мазепова О. В. \\ доктор філологічних наук, дочент, \\ завідувач кафедри мов і літератур Близького та Середнього Сходу \\ Інституту філології \\ Київького національного університету імені Тараса Шевченка \\ м. Київ, Украӥна
}

Поняття добра і зла відносяться до архетипних уявлень людства, яким притаманний бінарний характер. Такі бінарні опозиції, як «верх-низ», «далеко-близько», «гарно-погано», «багато-мало», «право-ліво», «свій-чужий» та ін. в сучасній науці розглядаються як базові опозиції культури, які сягають найдавніших часів, коли людина тільки-но починала осягати світ навколо себе і своє місце в ньому.

Реконструюючи лексико-семантичну систему індоєвропейської прамови, Т. Гамкрелідзе і В. Іванов вказували на те, що соціальній організації давнього індоєвропейського суспільства був притаманний дуальний характер, який накладав глибокий відбиток на характер всього духовного життя давніх індоєвропейців і визначав бінаризм, двоїстість у багатьох сферах релігійних і міфологічних уявлень та деяких рис моделі реального світу [2, с. 776$]$.

Двоїстість як принцип організації Всесвіту була притаманна й архетипному мисленню давніх іранців, що знайшло найяскравіший вияв у їхній релігійній системі - зороастризмі. Як зазначає С. Соколов, «найхарактернішою рисою зороастризму, що впадає в око при першому ж ознайомленні, $є$ його різко виражений дуалізм - визнання у світі двох начал, доброго і злого, боротьба котрих і складає сенс існування світу» $[6$, с. 13]. Особливістю цієї боротьби в зороастризмі є те, що уособлені поняття Добра i Зла, які протистоять одне одному, корелюють із поняттями Правди і Брехні таким чином, що Добро і Правда, з одного боку, під проводом бога Агура-Мазди (букв. Мудрий Господь) борються разом проти Зла і Брехні, з другого боку, воїнство яких очолює злий дух Ангра-Майнью (букв. Ворожа Думка).

Усі відомості стосовно цих понять сходять до Авести - найдавнішої й найважливішої пам'ятки іранської словесності, яка дійшла до нас як зібрання священних текстів зороастризму - державної релігії 
сасанідського Ірану в період, що передував арабському завоюванню (VII ст. н.е.). Нинішній текст Авести становить зібрання фрагментів, що зберіглися після приходу ісламу на територію Ірану, й були певним чином систематизовані. Особливе значення мають Гати (букв. пісні) «звернені до людини проповіді й одкровення Заратуштри, в яких він закликає відректися від світу зла і пітьми і обрати світ добра і світла» $[5$, c. 83].

Саме в Гатах вперше згадується Агура-Мазда, який керує праведним світом у двох своїх проявах: vohu mana Добра Думка та aša vahišta Краща Правда. До воїнства Добра, очолюваного ним, входять шість божественних абстрактних сутностей атеša spentā Безсмертні Святі, серед яких: vohu mana Добра Думка, aša vahišta Кращца Правда, xšathra vairya Добре Царство або Бажана Влада, spentā ārmayti Святе Благочестя, haurvatāt Цілісність, amertāt Безсмертя [1, с. 46]. 3-поміж небесних сил, що воюють на боці Агура-Мазди, - божественна сутність sraoša Слухняність (добрий дух, що передає людині волю небес i оберігає ії від зла), fravaši (безсмертні духи, янголи-охоронці всіх істот) та інші язати ${ }^{2}$ [5, с. 90-91].

Злий дух Ангра-Майнью у боротьбі з Добром також має військо, яке не поступається війську Агура-Мазди. До нього належать деви - колишні божества, персоніфіковані негативні поняття, такі як заздрість, лінощі, брехня, злі духи, колдуни і пері, які шкодять вогню, землі, воді й худобі, а також негативні герої, злі володарі тощо [4, с. 14]. Поступово в зороастрійській літературі було вироблено точну систему відповідників, де кожній праведній сутності протистояв певний дев. Проте головним протиставленням усього зороастризму є, з одного боку, Аша (або Аpma) «Правда», а з іншого - Друдж (або Друг) - «Брехня»; світ Агура-Мазди це світ Правди, світ Ангра-Майнью - світ Брехні. Прибічник першого називався словом ашаван «правовірний», прибічник другого друджвант «невірний» [6, с. 15].

Важливе місце в цій боротьбі відводилося людині. Їй надавалося право стати на бідь-який бік - Добра чи Зла. Головна мета правовірних полягала в допомозі Агура-Мазді в його боротьбі з Агріманом, активній діяльності, посильній участі у цій космічній битві. Зміст активної позиції праведних людей визначався відомою зороастрійською тріадою: humata

${ }^{2}$ Авест. yazata (н.-перс. izzad, мн. yazdān Бог) букв. «достойний поклоніння», «божество». Деякі язати постають в Авесті як духи-охоронці небесних світил, повітря, землі, вогню, води; інші - як персоніфікації абстрактних ідей (Перемоги, Істини тощо) [5, с. 91].

178 
Добра думка, hūxta Добре слово, hvaršta Добра справа, якій протиставлялася тріада невірних: dujmata Зла думка, dujuxta Зле слово, dujvaršta 3ла справа [6, с. 19].

Отже, етичні поняття добра і зла, правди і неправди в давньоіранській мовній свідомості постають як тісно взаємопов'язані між собою. Обираючи Добро, давній іранець зобов'язувався «казати правду», аби наблизити остаточну перемогу Добра над Злом.

3 лінгвістичного погляду авестійське слово аša правда є похідним від індо-іранського *rtá-, іменника середнього роду з тим же значенням. У свідомості давніх іранців поняття аša сприймалося з уособленням існували уявлення про однойменну безтілесну сутність, до якої можна було звертатися 3 молитвами або проханнями і приносити в жертву ритуальний напій хаома ${ }^{3}$. Авестійське слово druj брехня за формою $є$ іменником жіночого роду. Поняття druj уособлювалося у вигляді жіночої істоти, яка вступала в заборонені стосунки з грішниками і таким чином народжувала своїх незчисленних шкідливих виплодків [6, с. 15; 8].

Що стосується давньоперського мовно-культурного ареалу, представленого періодом правління Ахеменідів (VI-IV ст. до н.е.), то тут так само простежується синкретизм опозицій добро - зло, правда неправда. За спостереженням Р. Фрая, у грецьких джерелах досить часто «схвалення artā «чесності» та засудження drauga «брехні» відзначалися як якості, притаманні персам» [7, с. 149]. Зокрема, Геродот у своїй праці «Історії» писав, що своїх синів від п'яти до двадцяти років перси навчають трьох речей: «їздити верхи, стріляти 3 луків і казати правду» $[3$, с. 54]. Там же він стверджував, що «найганебнішою справою у них уважається казати неправду» [3, с. 55].

У наскельних написах ахеменідського царя Дарія, як вказує Р. Фрай, «постійно підкреслюється значення Правди і проклинається Брехня» [7, с. 163]. У давньоперських текстах корінь druj / drug репрезентований словом drauga- та деякими дієслівними особовими формами в контексті ствердження легітимності влади династії Ахеменідів [8]. Наприклад, це має місце у таких уривках з Бегестунського напису:

1) »ya $9 \bar{a}$ ka $^{\mathrm{m}}$ būj̆iya mudrāyam ašyava pasāva kāra arīka abava pasava drauga dahyauva vasaiy abava utā pārsaiy utā mādayi utā an yầ uva dahušuvā...» Коли Камбіз попрямував до Сгипту, народ став ворожим, $i$ потім стало у країні багато брехні: $i$ в Персї̈, $i$ в Мідії, $i$ в інших провіниіях...;

${ }^{3}$ Про напій хаома у давніх іранців див.: [1, с. 22-23]. 
2) »hauv kārāhyā ava9ā adrujua adam bṛdiya a ${ }^{\mathrm{h}}$ miy haya kūrauš pu $\vartheta^{\mathrm{r}} \mathrm{a}$ ka ${ }^{\mathrm{m}}$ būjiyahyā brātā...» Він так народу брехав: я є Бардія, котрий син Кіра, брат Камбіза... [5, с. 114-115].

В одному з персепольських написів Дарія брехня постає як одне 3 трьох найстрашніших лих, двома іншими 3 яких $\epsilon$ «ворожа армія» (hainā-) та «Голод» (dušiyāra-) [8]:

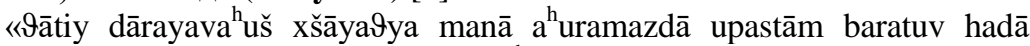

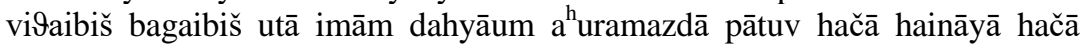
dušiyārā hačā draugā abiy imām dahyāum mā ājamyā mā hainā mā dušiyāram mā drauga...» Промовляє Дарій иар: «Нехай принесе мені Агура-Мазда допомогу разом з богами - захисниками роду. I июю крайну нехай захистить Агура-Мазда від ворожої армії, від голоду, від брехні! Нехай не спіткає иңю країну ані ворожа армія, ані голод, а ні брехня...» [5, с. 132-133].

Отже, як можна виснувати 3 усього вищенаведеного, в мовнокультурному просторі стародавнього Ірану дихотомія добро - зло існувала в синкретизмі 3 опозицією правда - неправда. Ці дві концептуальні опозиції в свідомості давніх іранців були нероздільні, i кожна праведна людина, стаючи на бік Добра в його споконвічній боротьбі зі Злом, водночас брала на себе зобов'язання говорити Правду і протистояти Брехні.

\section{Література:}

1. Бойс М. Зороастрийцы: верования и обычаи. Пер. с англ. и прим. И.М. Стеблин-Каменского. Санкт-Петербург: Азбука-классика; Петербургское Востоковедение. 2003. 352 с.

2. Гамкрелидзе Т.В., Иванов В.В. Индоевропейский язык и индоевропейцы. Реконструкция и историко-типологический анализ праязыка и протокультуры. В 2 т. Тбилиси: Изд-во Тбилисского университета, 1984.

3. Геродот. Історії в дев'яти книгах; переклад, передмова та примітки А.О. Білецького. Київ: Наукова думка, 1993. 574 с.

4. Дорошенко Е.А. Зороастрийцы в Иране. (Историкоэтнографический очерк). Москва: Наука. Главная редакция восточной литературы изд-ва «Наука», 1982. 133 с.

5. Оранский И.М. Введение в иранскую филологию. Москва: Главная редакция восточной литературы изд-ва «Наука», 1988. 390 с.

6. Соколов С.Н. Древнейшая религия иранских племен. Авеста в русских переводах (1861-1996) / Ред. И.В. Рак. Санкт-Петербург: Журнал «Нева», 1997. С. 7-21. 
7. Фрай Р. Наследие Ирана. Пер. с англ. В.А. Лившица и Е.В. Зеймаля; под ред. и с предисл. М.А. Дандамаева. 2-е изд., испр. и доп. Москва: Восточная литература, 2020. 463 с.

8. Kellens J. Druj-/ Encyclopeadia Iranica, Online Edition, 1996. URL: http://www.iranicaonline.org/articles/druj. Дата звернення: 20.02.2021.

DOI https://doi.org/10.30525/978-9934-26-039-1-46

\title{
ПОРІВНЯЛЬНО-КОНЦЕПТУАЛЬНИЙ АНАЛІЗ ТВОРІВ В. ВУЛФ ТА ДЖ. ДЖОЙСА
}

\author{
Матковська М. В. \\ доиент кафедри англійської мови \\ Кам'янець-Подільського національного університету \\ імені Івана Огієнка \\ м. Кам'янеиь-Подільський, Хмельницька область, Украӥна
}

Вірджинія Вулф (1882-1941), британський романіст, есеїст і критик, сприяла створенню сучасного роману. В іiі роботах часто досліджується концепти часу, пам'яті і внутрішньої свідомості людей.

Джеймс Джойс (1882-1941), представник ірландської модерністської і постмодерністської прози, виступив як засновник нової поетики, нових способів письма, в яких форма по суті репрезентує зміст, кодуючи в собі моральні, естетичні, психологічні і інші вимірювання.

Концепти, які ми досліджуємо в творах В. Вулф та Дж. Джойса, виражають певні емоції й наміри. Існують шість емоцій, які універсально свіввідносяться 3 мімікою обличчя: щастя, печаль, гнів, страх, здивування та інтерес. Різні похідні слова, подібно до англійського 'досада', 'дратування', показують слабкіші або сильніші ефекти прототипу, в даному випадку, від прототипічного 'гнів'. Вони не завжди володіють прямими еквівалентами в іншій мові ('досада' - в польській або російській мовах розуміється як конструктивний термін, що об'єднує два різні прототипи: 'гнів' і ‘печаль').

Наша мета - визначити специфіку аналізу порівняльно-концептуального простору в творах В. Вулф та Дж. Джойса.

Конецпт намірів походить онтогенетично від примітивного концепту хотіти. Обидва вони передують таким концептам як иџілі й плани, які можна вивести шляхом умовиводу як орієнтовані концепти. 